\title{
Commercial Speech Law and Tobacco Marketing: A Comparative Discussion of the United States and Canada
}

\author{
Micah L. Berman ${ }^{\dagger}$
}

\section{INTRODUCTION}

In November 2011, U.S. District Court Judge Richard Leon ruled that the U.S. Food and Drug Administration's (FDA's) proposed graphic health warnings for cigarette packages violated tobacco companies' First Amendment rights. ${ }^{1}$ In doing so, he pointedly refused to consider the experiences of Canada, the United Kingdom, and the more than thirty other countries that had adopted similar graphic warnings in the past decade. Rather, he swatted away all references to those other countries' experiences by stating (first at oral argument and then in his decision) that "none of [those countries] afford First Amendment protections like those found in our Constitution."2

While it is true that no other country uses the First Amendment per se, many other countries $d o$ offer constitutional protection to freedom of speech and/or freedom of expression. ${ }^{3}$ Indeed, several other countries apply "strikingly similar" legal tests when reviewing restrictions on speech (and on commercial speech in particular). ${ }^{4}$ Thus, the statement that other countries do not "afford First Amendment protections like those found in our Constitution" is an oversimplification. ${ }^{5}$ Rather

† Assistant Professor of Health Policy and Law at Ohio State University's College of Public Health and Moritz College of Law.

'R.J. Reynolds Tobacco Co. v. FDA, 823 F. Supp. 2d 36 (D.D.C. 2011), aff'd, 696 F.3d 1205 (D.C. Cir. 2012). This decision was affirmed by the appellate court and the FDA elected not to seek review by the Supreme Court.

${ }^{2}$ Id. at $48 \mathrm{n} .21$ (emphasis added).

${ }^{3}$ See Ronald J. Krotoszynski, Jr., The Chrysanthemum, the Sword, and the First Amendment: Disentangling Culture, Community, and Freedom of Expression, 1998 WIS. L. REv. 905, 905 (1998).

${ }^{4}$ Guy E. Carmi, Dignity Versus Liberty: The Two Western Cultures of Free Speech, 26 B.U. INT'L L.J. 277, 369 (2008).

${ }^{5}$ R.J. Reynolds Tobacco Co., 823 F. Supp. $2 \mathrm{~d}$ at $48 \mathrm{n} .21$ (emphasis added). Also lost in Judge Leon's dismissal of the experiences of other countries is that those experiences provide a highly probative form of evidence. Even if the precise details of legislation are different (e.g., the warnings labels in other countries are not identical to those proposed by the FDA), the experiences of foreign countries are still relevant to the First Amendment tests laid down by the Supreme Court. For example, the Central Hudson test used to review restrictions on commercial speech asks the government to demonstrate whether the proposed restriction "directly advances the government interest asserted." Cent. Hudson Gas \& Electric Corp. v. Pub. Serv. Comm'r of N.Y., 447 U.S. 557, $566(1980)$. Evidence from other countries' experiences can help to inform this analysis. 
than ignore how other countries have addressed tensions between freedom of expression and other societal interests (such as public health), a comparative analysis can help enrich our understanding of the First Amendment by introducing new perspectives and doctrinal considerations that may challenge our settled assumptions. $^{6}$

Applying a comparative perspective, this Article will focus on the protection afforded to commercial speech, ${ }^{\prime}$ and to tobacco advertising in particular. For purposes of this Issue, I will focus solely on the example of Canada. Like the United States, Canada has a constitutional provision that protects freedom of speech, and in commercial speech cases it applies a balancing test that is almost identical to the Central Hudson test used by U.S. courts. ${ }^{8}$ It is important to emphasize, however, that the case of Canada is not unique in these respects. Other countries and jurisdictions-including South Africa, ${ }^{9}$ Japan, ${ }^{10}$ and the European Union ${ }^{11}$-also use Central Hudson-like balancing tests when reviewing restrictions on commercial speech. Each jurisdiction has come to its own conclusions about how to best balance commercial speech rights against the challenge of regulating tobacco marketing. My discussion of Canada's approach is presented here as one example of a broader comparative analysis that could be undertaken.

Carefully examining how other countries strike the balance between free expression and public health could lead to a productive reexamination of the First Amendment's commercial speech doctrine and its purpose. In particular, as the example of Canada demonstrates, a comparative discussion can help to reintroduce the interests of the consumer into the debate over commercial expression rights. From the perspective of the consumer, not all commercial speech is equally

${ }^{6}$ Cf. Krotoszynski, supra note 3 , at 913 (suggesting that "examination of freedom of speech in Japan leads to a more insightful understanding of our domestic speech rights and a heightened awareness of the implicit costs and benefits associated with maintaining these rights").

${ }^{7}$ There is no clear definition of "commercial speech." In Bolger v. Youngs Drug Products Corp., the Supreme Court suggested that following factors should be considered in determining whether speech is commercial: (1) whether the speech proposes a commercial transaction, (2) whether the speech references a specific product, and (3) whether the speaker is motivated by economic aims. See Bolger v. Youngs Drug Prods. Corp., 463 U.S. 60, 66-76 (1983).

${ }^{8}$ See Canadian Charter of Rights and Freedoms, Part I of the Constitution Act, 1982, §§ 1-2; see also R. v. Oakes, [1986] 1 S.C.R. 103 (Can.).

${ }^{9}$ See S. AFR. CONST., $1996 \S \S 16,36$ (protecting freedom of expression, but allowing for such a right to be limited under a balancing test taking into account " $a$. the nature of the right; $b$. the importance of the purpose of the limitation; $c$. the nature and extent of the limitation; $d$. the relation between the limitation and its purpose; and e. less restrictive means to achieve the purpose"). These provisions were recently applied to restrictions on tobacco marketing in British American Tobacco South Africa Ltd. v. Minister of Health 2012 (3) SA 593 (SCA) (S. Afr.).

${ }^{10}$ See Krotoszynski, supra note 3, at 931-33 (discussing Japan's constitutional protection for freedom of speech and noting that like the U.S. Supreme Court, "the Supreme Court of Japan routinely has balanced the individual's interest in freedom of expression against other private interests and public interests").

${ }^{11}$ Nearly all countries in Europe are parties to the 1953 European Convention for the Protection of Human Rights and Fundamental Freedoms. See Convention for the Protection of Human Rights and Fundamental Freedoms, CouNCIL OF EUR. (Mar. 3, 2013), http://conventions.coe.int/Treaty/ Commun/ChercheSig.asp?NT $=005 \& \mathrm{CM}=\& D F=\& C L=E N G$. While not a constitution, the Convention is binding on all member states, and its provisions are enforced by the European Court of Human Rights. See Convention for the Protection of Human Rights and Fundamental Freedoms, Nov. 4 1950, E.T.S. 5, 213 U.N.T.S. 221 (Nov. 4, 1950), available at http://conventions.coe.int/treaty/en/treaties/ $\mathrm{html} / 005 \mathrm{htm}$. The Convention protects freedom of expression, including commercial expression, and its protections are "similar theoretically and conceptually" to those provided by the First Amendment. Bruce E.H. Johnson \& Kyu Ho Youm, Commercial Speech and Free Expression: The United States and Europe Compared, 2 J. INT'L MEDIA \& ENT. L. 159, 161 (2009). 
valuable, and not all government restrictions on speech infringe upon consumer autonomy. To the contrary, regulations on speech can protect consumers from the deceptive and manipulative marketing of harmful products such as tobacco.

\section{COMMERCIAL SPEECH \& TOBACCO ADVERTISING IN THE UNITED STATES}

To make the comparison with Canada, it is first necessary to quickly review how the U.S. Supreme Court has approached commercial speech cases. The First Amendment states, "Congress shall make no law . . . abridging the freedom of speech, or of the press ...."12 Although the text is unqualified, suggesting that freedom of speech can never be restricted, the Supreme Court has developed a complex set of First Amendment doctrines that apply different levels of protection to different types of speech. ${ }^{13}$ These doctrines-including the commercial speech doctrine-are non-textual judicial creations whose applications vary over time and with changes in the Supreme Court's makeup. ${ }^{14}$

\section{A. The Supreme CourT's Commercial SpeEch Doctrine}

Before the mid-1970s, the Supreme Court did not consider commercial speech to be protected by the First Amendment at all. ${ }^{15}$ In a series of cases culminating in Virginia State Board of Pharmacy v. Virginia Citizens Consumer Council (1976), the Supreme Court changed course and decided that the First Amendment's protections extended to commercial speech. ${ }^{16}$ In Virginia Pharmacy, the Court struck down a Virginia regulation that prohibited pharmacists from advertising the price of prescription drugs. ${ }^{17}$ In the course of its decision, the Court (in an opinion by Justice Blackmun) provided three reasons why commercial speech should be entitled to First Amendment protection. ${ }^{18}$ As summarized by Eric Barendt:

\footnotetext{
${ }^{12}$ U.S. CONST, amend. I.

${ }^{13}$ For instance, even religious and political speech can be subjected to "time, place, and manner" limitations, so long as such restrictions are content-neutral. See, e.g., Pleasant Grove City v. Summum, 555 U.S. 460,469 (2009).

${ }^{14}$ See Carlos E. González, The Logic of Legal Conflict: The Perplexing Combination of Formalism and Anti-Formalism in Adjudication of Conflicting Legal Norms, 80 OR. L. REV. 447, 468 n.34 (2001).

is See Valentine v. Chrestensen, 316 U.S. 52, 54 (U.S. 1942) ("We are equally clear that the Constitution imposes no such restraint on government as respects purely commercial advertising.").

${ }^{16}$ See Va. State Bd. of Pharmacy v. Va. Citizens Consumer Council, 425 U.S. 748 (1976).

${ }^{17} \mathrm{Id}$. at 770 (holding that the state is "free to require whatever professional standards it wishes of pharmacists" but that "it may not do so by keeping the public in ignorance of the entirely lawful terms that competing pharmacists are offering").

${ }^{18}$ Id. at $764-70$.
} 
The first focused on the interests of consumers in the free flow of commercial information: "[T]hat interest may be as keen, if not keener by far, than his interest in the day's most urgent political debate.' Secondly, society has a strong interest in the unimpeded flow of commercial information, partly because that information may have a public interest component, but more generally because the flow is important in enabling consumers to make informed choices, which cumulatively are essential to the working of a free-enterprise economy. Thirdly, for the state to justify its ban on the publication of drug prices with the argument that otherwise consumers would be attracted to go to low-cost, low-quality pharmacist is unacceptable paternalism. ${ }^{19}$

In short, the majority in Virginia Pharmacy reasoned that commercial speech should be protected because of the interests of the consumer in obtaining information needed to make decisions, even if those decisions are purely economic in character. ${ }^{20}$ (Note that the plaintiff in Virginia Pharmacy was a consumer group interested in obtaining price-related information, not a pharmacist looking to distribute such information.) $)^{21}$

Virginia Pharmacy balanced the consumers' interest in obtaining price-related information against the state's argument that the regulation was needed to protect the professionalism of pharmacists. Suggesting that the regulation seemed more like a protectionist measure meant to ensure higher drug prices than a bona fide measure to ensure professionalism, the Court ruled that regulation was invalid. ${ }^{22}$ It left open the question of how such balancing should be conducted in future cases-an issue that the Court addressed four years later in Central Hudson.

In Central Hudson, the Court developed a four-pronged test that has been used for the past twenty-plus years to review restrictions on commercial speech. ${ }^{23}$ The Central Hudson test provides:

1. To qualify for First Amendment protection, the commercial speech must concern lawful activity and not be misleading. ${ }^{24}$

2. The government's asserted interest in restricting the speech must be substantial. $^{25}$

3. The restriction must directly advance the government's asserted interest. $^{26}$

4. The restriction must not be more extensive than necessary to serve the asserted government interest. ${ }^{27}$

This test is a form of "intermediate scrutiny." 28 It provides some protection to commercial speech, but is clearly a less rigorous form of review than that afforded to

19 ERIC BARENDT, FREEDOM OF SPEECH 400-01 (2d. ed. 2005) (footnotes omitted). Justice Rehnquist dissented from the opinion, objecting to the creation of a new commercial speech doctrine that "elevates commercial intercourse between a seller hawking his wares and a buyer seeking to strike a bargain to the same plane as has been previously reserved for the free marketplace of ideas." Va. State Bd. of Pharmacy, 425 U.S. at 781 (1976) (Rehnquist, J., dissenting).

${ }^{20}$ The second and third reasons listed by Justice Blackmun both relate back to the interest in ensuring that consumers are able to obtain access to information. $I d$. at 764-70.

${ }^{21}$ Id. at $753-54$.

${ }^{22}$ Id. at 769 .

${ }^{23}$ Cent. Hudson Gas \& Elec. Corp. v. Pub. Serv. Comm'n, 447 U.S. 557, $564-66$ (1980).

${ }^{24} I d$. at 564 .

${ }^{25} I d$.

${ }^{26} I d$. at 566 .

${ }^{27}$ See id. 
"core" First Amendment speech such as political speech. ${ }^{29}$ Courts are, in effect, asked to balance the government's interest in restricting the speech against the constitutional value of the commercial speech at issue. ${ }^{30}$ Although the Central Hudson test provides a framework for courts to use in reviewing commercial speech cases, it does not provide any clear guidance as to how the framework is to be applied in any particular case. Whether a regulation is "more extensive than necessary," for example, is a context-specific judgment call not amenable to broad generalizations. $^{31}$

What can be said, however, is that the Court has, over time, been less willing to defer to a legislature's conclusion that a particular restriction on speech is required. Though it continues to apply Central Hudson's intermediate standard of review, in recent years the Court has "continued to strike down commercial speech regulations under what increasingly has looked like a strict scrutiny standard." ${ }^{32}$ A few key points in the Court's progression towards a more demanding standard of review are summarized below:

- 1993: In Edenfield v. Fane, the Court appeared to raise the evidentiary burden placed on the government, writing that the state must show that the proposed restriction will advance its interest "to a material degree," and suggesting that specific studies may be needed to support a restriction on commercial speech. ${ }^{33}$

- 1996: In 44 Liquormart v. Rhode Island, the Court rejected the argument that since the government could completely ban "vice" activities such as drinking or gambling, it should be able to more freely regulate commercial speech relating to such activities. ${ }^{34}$ Earlier commercial speech decisions had accepted such an argument. ${ }^{35}$

- 2002: In a five-to-four ruling in Thompson v. Western States Medical Center, the Court stated: "[W]e have made clear that if the Government could achieve its interests in a manner that does not restrict speech, or that restricts less speech, the Government must do so."36 In other words, it suggested that a restriction on commercial speech must be the last resort, if non-speech-related options were available.

In its most recent commercial speech case, Sorrell v. IMS Health Inc. (2011), the Court suggested that "heightened scrutiny" should apply to commercial speech cases, intimating that the Central Hudson test might be replaced with a more

${ }^{28} \mathrm{Id}$. at 573 (Blackmun, J., concurring) (characterizing the four-part test applied by the majority as a form of intermediate scrutiny).

${ }^{29}$ See id. at 563 ("The Constitution therefore accords a lesser protection to commercial speech than to other constitutionally guaranteed expression.").

${ }^{30}$ See id. ("The protection available for particular commercial expression turns on the nature both of the expression and of the governmental interests served by its regulation.").

${ }^{31} I d$. at 566 .

${ }^{32}$ Samantha Rauer, Note, When the First Amendment and Public Health Collide: The Court's Increasingly Strict Constitutional Scrutiny of Health Regulations that Restrict Commercial Speech, 38 AM. J.L. \& MED. 690, 693 (2012).

${ }^{33}$ Edenfield v. Fane, 507 U.S. 761, 771 (1993) (invalidating limits on the solicitation of business by accountants).

${ }^{34} 44$ Liquormart v. Rhode Island, 517 U.S. 484, $511-14$ (1996) (striking down a Rhode Island law that limited the advertisement of prices for alcoholic beverages).

${ }^{35}$ See Posadas de P.R. Assocs. v. Tourism Co. of P.R., 478 U.S. 328, $345-46$ (1986) (upholding a statute limiting advertising for casino gambling in Puerto Rico by concluding that "the greater power to completely ban casino gambling includes the lesser power to ban advertising of casino gambling").

${ }^{36}$ Thompson v. W. States Med. Ctr., 535 U.S. 357, 371 (2002) (invalidating FDA regulations restricting the advertising of compounded pharmaceuticals). 
stringent standard. ${ }^{37}$ Ultimately, the Court reaffirmed Central Hudson as the appropriate test, but wrote, "[T]he State may not seek to remove a popular but disfavored product from the marketplace by prohibiting truthful, nonmisleading advertisements that contain impressive endorsements or catchy jingles. That the State finds expression too persuasive does not permit it to quiet the speech or to burden its messengers." Although the language of "disfavored product" brings to mind tobacco, ${ }^{39}$ it has yet to be seen whether or how the Court will apply this dicta to the case of tobacco marketing. ${ }^{40}$ Already, however, lower courts have cited this phrase in striking down restrictions on tobacco advertising. ${ }^{41}$

\section{B. TOBACCo AdVERTISING}

The Supreme Court has only decided one case that directly applied the Central Hudson test in the specific context of limits on tobacco advertising. In that case, Lorillard $v$. Reilly, the Supreme Court struck down a Massachusetts regulation barring outdoor tobacco advertisements within 1000 feet of a school or playground. ${ }^{42}$ The Court addressed the first two prongs of the Central Hudson test quite summarily. It noted that Massachusetts had conceded (for purposes of the summary judgment motion before the Court) that the speech at issue was not misleading or related to illegal conduct, and that the tobacco companies had conceded that the state had a significant interest in reducing tobacco use by minors. ${ }^{43}$ With respect to the third prong, the Court conducted a more thorough analysis before concluding that the state regulation would indeed advance the government interest asserted. ${ }^{44}$ Thus, the case turned on the Court's analysis of Central Hudson's fourth prong, which asks "whether the speech restriction is not more extensive than necessary to serve the interest that support it." 45

The Court concluded that the prohibition on advertising within 1000 feet of a school or playground was more extensive than necessary for several reasons. First, the Court noted that such a restriction would, in some geographical areas, "constitute nearly a complete ban on the communication of truthful information about

${ }^{37}$ Sorrell v. I.M.S. Health Inc., 131 S. Ct. 2653, 2664 (2011) (voiding a Vermont law barring pharmaceutical companies from using pharmacy records showing the prescribing practices of individual physicians in their marketing efforts).

${ }^{38} I d$. at 2671 .

${ }^{39}$ This is the tobacco companies' preferred language. When referring to tobacco, "deadly" would be a more appropriate adjective than "disfavored."

${ }^{40}$ See Micah Berman, Kathleen Dachille \& Julie Ralston Aoki, Sorrell and the Future of Commercial Speech Regulations, JURIST (Oct. 4, 2011), http://jurist.org/forum/2011/10/bermandachille-aoki-sorrell.php (suggesting that Sorrell is distinguishable from tobacco-related cases and might not signify a significant shift in the way courts addresses advertising restrictions on harmful products).

${ }^{41}$ See, e.g., Nat'l Ass'n of Tobacco Outlets v. City of Worcester, 851 F. Supp. 2d 311,319 (D. Mass. 2012) ("Under Sorrell, the City of Worcester may not seek to remove a popular but disfavored type of products-those products that serve tobacco usage-from the marketplace by prohibiting truthful, nonmisleading advertisements directed to adults.").

${ }^{42}$ Lorillard v. Reilly, 533 U.S. 525, 561-66 (2001). Technically, the decision struck down the limits with respect to cigarette advertising on other legal grounds. See id. at 550-51 (striking down Massachusetts's regulation on outdoor and point of sale cigarette advertising on the grounds of federal preemption). It struck down the limits on cigar and smokeless tobacco advertising on First Amendment grounds. See id. at 566.

${ }^{43} \mathrm{Id}$. at 554 .

${ }^{44}$ See id. at 558-61 (internal quotation marks omitted).

${ }^{45} \mathrm{Id}$. at 556 (quoting Greater New Orleans Broad. Ass'n, Inc. v. United States, 527 U.S. 173, 188 (1999)) (internal quotation marks omitted). 
smokeless tobacco and cigars to adult consumers." ${ }^{46}$ This was because the regulations prohibited not only outdoor advertising, such as billboards, but also indoor advertising that was visible from outside. ${ }^{47}$ As the Court noted, retailers would not even be permitted to communicate to passers-by that tobacco products were available for sale. ${ }^{48}$ Second, it appeared that the Massachusetts Attorney General had failed to consider the impact of the restriction in major metropolitan areas and had instead adopted the 1000 foot measure from the FDA's proposed 1996 rule (which has been struck down by the Supreme Court-on grounds unrelated to the First Amendment-in 2000) without any analysis. ${ }^{49}$ The failure to consider the degree to which the restriction might suppress advertising suggested a "lack of tailoring." ${ }^{50}$ Third, the broad definition included in the restriction-which appeared to restrict oral, as well as printed, communications-seemed broader than necessary to achieve the state's interest. ${ }^{51}$ Together, all of these factors led the Court to find that the regulation did not satisfy the fourth prong of the Central Hudson test. ${ }^{52}$

In my view, Lorillard was a much narrower decision than it is often taken to be. Taking the Supreme Court at its word, the Massachusetts regulations might have been upheld if (a) they applied only to outdoor advertising, and not to advertisements visible from outdoors (and allowed retailers to signal the availability of tobacco products), (b) they did not include a restriction on oral communication, and (c) the Massachusetts Attorney General had provided a better justification for selecting the 1000-foot distance. Nonetheless, Lorillard has often been read (or misread) for the much more general proposition that restrictions on tobacco advertising are presumptively unconstitutional. ${ }^{53}$ While this seems to me to be a gross exaggeration of Lorillard's holding, it is nonetheless consistent with the direction the courts have taken on commercial speech issues in the years since Lorillard. ${ }^{54}$

In sum, although the tobacco-specific case law is not well developed, the U.S. Supreme Court has been increasingly skeptical of restriction on commercial speech. ${ }^{55}$ The Supreme Court's key commercial speech decisions over the past two

\footnotetext{
${ }^{46} I d$. at 562 .

${ }^{47}$ See id.

${ }^{48}$ See id. at 565.

${ }^{49}$ See id. at 562-63.

${ }^{50} \mathrm{Id}$. at 563 .

51 See id.
}

52 See id. at 565 ("We conclude that the Attorney General has failed to show that the outdoor advertising regulations for smokeless tobacco and cigars are not more extensive than necessary to advance the State's substantial interest in preventing underage tobacco use.").

${ }^{53}$ See, e.g., Clay Calvert, Wendy Allen-Brunner \& Christina M. Locke, Playing Politics or Protecting Children? Congressional Action \& A First Amendment Analysis of the Family Smoking Prevention and Tobacco Control Act, 36 J. LEGIS. 201, 205 (2010) (suggesting that the tobacco advertising restrictions in the Tobacco Control Act, Pub. L. No. 111-31, 123 Stat. 1776 (2009) (to be codified at 15 U.S.C. $\S 1333$ (labeling), 15 U.S.C. $\S 4402$ (smokeless tobacco warning), 21 U.S.C. $\S 387 \mathrm{a}-1$ (final rule)), "seem[] to have been crafted behind a veil of legal ignorance-or, perhaps, a willful blindness-of Lorillard and pertinent academic scholarship surrounding it"); Michael Hoefges, Protecting Tobacco Advertising Under the Commercial Speech Doctrine: The Constitutional Impact of Lorillard Tobacco Co., 8 COMM. L. \& POL'Y 267, 305 (2003) (writing that the Lorillard decision "effectively places tobacco advertising on the same constitutional level as advertising for other lawful goods and services under the First Amendment" and suggests that restrictions intended to protect children from tobacco advertising are likely to be invalidated).

${ }_{54}^{54}$ See generally Rauer, supra note 32.

${ }^{55}$ The Supreme Court may agree to review a case challenging the advertising restrictions in the Family Smoking Prevention and Tobacco Control Act in the coming year. Discount Tobacco City \& Lottery, Inc. v. United States, 674 F.3d 509 (6th Cir. 2012), petition for cert. filed sub nom. Am. Snuff 
decades-44 Liquormart, Western States, and Sorrell-all suggest that it may now be harder than in the past for restrictions on tobacco advertising to survive the Court's review.

\section{COMMERCIAL SPEECH AND TOBACCO ADVERTISING IN CANADA}

As shown below, Canada applies a standard of review in commercial speech cases that closely parallels the Central Hudson test. Although the Canadian Supreme Court is not as protective of commercial speech as its U.S. counterpart, it carefully reviews laws that curtail commercial speech and has not hesitated to strike down laws it views as unconstitutional restrictions on free expression. ${ }^{56}$ Twice in the last two decades, the Canadian Supreme Court has had the opportunity to apply its commercial speech jurisprudence to restrictions on tobacco advertising.

\section{A. Canadian Commercial Speech Law}

Until 1982, Canada did not provide any explicit constitutional protection for freedom of speech. ${ }^{57}$ Thus, all of Canada's free speech jurisprudence (not only its commercial speech jurisprudence) is of relatively recent vintage. The Canadian Charter of Rights and Freedoms, adopted as part of Canada's Constitution in 1982, functions as Canada's version of the Bill of Rights. ${ }^{58}$ Sections 1 and 2 of the Charter provide as follows:

1. "The Canadian Charter of Rights and Freedoms guarantees the rights and freedoms set out in it subject only to such reasonable limits prescribed by law as can be demonstrably justified in a free and democratic society." 59

2. "Everyone has the following fundamental freedoms:

(a) freedom of conscience and religion;

(b) freedom of thought, belief, opinion and expression, including freedom of the press and other media of communication;

(c) freedom of peaceful assembly; and

(d) freedom of association." 60

Section 2(b) is the relevant part of Section 2 for purposes of this discussion, and unlike the First Amendment it protects "freedom of expression," not just "freedom of speech." $"$ This is not a significant difference, however, as it apparently results from the drafters' recognition that much of what the First Amendment protects is not

Co., LLC v. United States, No. 12-521 (Oct. 26, 2012). This would give the Court the opportunity to further clarify its approach to the regulation of tobacco advertising.

${ }_{56}$ Roger A. SHINER, Freedom OF COMMERCIAL EXPRESSION 91 (2003) (noting that the Canadian Supreme Court has, like the U.S. Supreme Court, "struck down numerous . . provincial restrictions on professional advertising" and "invalidated restrictions controlling the advertising of, respectively, alcohol and tobacco").

${ }^{57}$ See id. at 70.

${ }^{58}$ See id.

${ }^{59}$ Canadian Charter of Rights and Freedoms, Part I of the Constitution Act, 1982, being Schedule B to the Canada Act, 1982, c. $11, \S 1$ (U.K.).

${ }^{60} \mathrm{Id}$. $\S 2$. Note that section 2 covers essentially the same subject matter as the First Amendment (religion, speech/expression, press, assembly/association).

${ }^{61}$ See SHINER, supra note 56, at 71. 
technically "speech" (artistic expression, silent protests, etc.) ${ }^{62}$ Another difference is that Section 1 "explicitly acknowledges . . . the possibility of valid limitations on charter rights and freedoms under certain conditions." ${ }^{\text {"T3 }}$ The First Amendment, by contrast, is absolute and does not explicitly provide for any exceptions. ${ }^{64}$ But as discussed above, the First Amendment is not absolute in practice, particularly when it comes to commercial speech. ${ }^{65}$ Despite according commercial speech constitutionally protected status, U.S. courts are required, in effect, to balance commercial speech interests against the strength of the governmental interests asserted. ${ }^{66}$ Section 1 of the Canadian Charter of Rights and Freedoms simply makes the need to balance competing interests explicit. ${ }^{67}$

Section 1 does not, however, give Canadian courts much guidance in determining how such balancing is to be conducted. The analysis under Section 1 was formalized by the 1986 case of $R$. v. Oakes ${ }^{68}$ (the "Oakes test"), which, as summarized by Roger Shiner, provides as follows:

1. The objective of the limitation must be sufficiently important to warrant overriding a constitutionally protected right or freedom. As a minimum, it must represent a pressing and substantial concern.

2. The means employed must be reasonable and demonstrably justified. The assessment of this takes the form of a three-part test of proportionality:

(i) The measures employed must be rationally connected to the objective.

(ii) The measures should impair the freedom no more than is necessary to accomplish the objective.

(iii) The effects of the impugned limit must not be disproportionate to the legislative objective sought. ${ }^{69}$

Unlike the Central Hudson test, which applies only to restrictions on commercial speech, the Oakes test is used to assess infringements on any rights provided for by the Charter. Notwithstanding that crucial difference, the two tests are remarkably similar in form, as the Canadian Supreme Court has noted. ${ }^{70}$ Part 1 of the test requires a finding that a constitutionally protected right is being infringed, which is analogous to the first prong of the Central Hudson test. ${ }^{71}$ Part 1 also

${ }^{62}$ See id.

${ }^{63}$ See id.

${ }^{64}$ See id. (contrasting Section 2 with the First Amendment).

${ }^{65}$ See supra note 13 and accompanying text.

${ }^{66}$ See supra notes 29-30 and accompanying text.

${ }^{67}$ Although the First Amendment is written in unqualified form while Canada's Constitution explicitly permits a balancing of competing interests, that distinction likely has little practical effect in the case of restrictions on commercial speech. Cf. Johnson \& Youm, supra note 11, at 195-96 ("As the commercial speech case law of the [U.S.] Supreme Court and the [European Court of Human Rights] indicates, it makes little difference whether the constitutional guarantee of freedom of speech or of the press is textually qualified or unqualified.").

${ }^{68}$ R. v. Oakes, [1986] 1 S.C.R. 103 (Can.).

${ }^{69}$ SHINER, supra note 56 , at 71.

${ }^{70}$ Ford v. Quebec (Att'y Gen.), [1988] 2 S.C.R. 712, 758 (Can.) (writing that the Central Hudson test is "an attempt to balance the legitimacy of government regulations intended to protect consumers from harmful commercial speech with the belief that a free market in ideas and information is necessary to an informed and autonomous consumer").

${ }^{71}$ See id. 
requires a "pressing and substantial" governmental concern, analogous to the second prong of Central Hudson. ${ }^{72}$ Part 2(i) demands a rational connection between the governmental interest and the means pursued. ${ }^{73}$ This corresponds to the third prong of Central Hudson, although "rational connection" may be a somewhat weaker standard than "directly advances." 74 Finally, Part 2(ii)'s requirement that the measure "impair the freedom no more than is necessary" is quite similar to the fourth prong of the Central Hudson test. ${ }^{75}$ (The final part of the Oakes test, Part 2(iii), does not have a direct correlate in the Central Hudson test.) ${ }^{76}$

It was not until the late 1980 s that the Supreme Court of Canada clarified the constitutional status of commercial speech. In Ford v. Quebec, the court affirmed that commercial speech was constitutionally protected, writing:

Given the earlier pronouncements of this Court to the effect that the rights and freedoms guaranteed in the Canadian Charter should be given a large and liberal interpretation, there is no sound basis on which commercial expression can be excluded from the protection of s.2(b) of the Charter.... Over and above its intrinsic value as expression, commercial expression which, as has been pointed out, protects listeners as well as speakers, plays a significant role in enabling individuals to make informed economic choices, an important aspect of individual self-fulfillment and personal autonomy. The Court accordingly rejects the view that commercial expression serves no individual or societal value in a free and democratic society and for this reason is undeserving of any constitutional protection. ${ }^{77}$

Like the U.S. Supreme Court in Virginia Pharmacy, the Canadian Supreme Court ascribed constitutional value to commercial speech primarily for its role in promoting consumers' interests in obtaining information and exercising their autonomy,

Since Ford, the Canadian Supreme Court has consistently held that commercial speech is within the protection of Section 2(b) ${ }^{78}$ In contrast to the U.S. Supreme Court, however, it does not consider commercial speech as a different category of speech requiring a separate legal doctrine. ${ }^{79}$ Rather, the Oakes test is applied to all

${ }^{72}$ Compare Oakes, 1 S.C.R. at 138-39, with Cent. Hudson Gas \& Elec. Corp. v. Pub. Serv. Comm'n, 447 U.S. 557, 564 (1980) ("The State must assert a substantial interest to be achieved by restrictions on commercial speech.").

${ }^{73}$ Oakes, 1 S.C.R. at 139.

${ }^{74}$ Cent. Hudson Gas \& Elec. Corp., 447 U.S. at 566.

${ }^{75}$ Compare Oakes, 1 S.C.R. at 139 , with Cent. Hudson Gas \& Elec. Corp., 447 U.S. at 566 ("[S]peech restrictions [must] be 'narrowly drawn.' The regulatory technique may extend only as far as the interest it serves.").

${ }^{76}$ SHINER, supra note 56 , at 72.

${ }^{77}$ Ford v. Quebec (Att'y Gen.), [1988] 2 S.C.R. 712, 766-67 (Can.) (emphasis added). According to Karla Gower, commercial speech had not been deemed to fall within Canada's protections for freedom of speech in the pre-Charter era. See Karla K. Gower, Looking Northward: Canada's Approach to Commercial Expression, 10 COMM. L. \& POL'Y 29, 36 (2005).

${ }^{78}$ See generally Gower, supra note 77, at 42-56 (summarizing Ford and its progeny).

${ }^{79} \mathrm{Id}$. at 45 (noting the Canadian Supreme Court's rejection of an approach to commercial speech that would involve defining it as a separate category of speech: "The Canadian Court made it clear that it did not want to get into the problem of trying to define commercial expression. It chose instead to take a purposive approach to determining whether the speech in question warranted Charter protection"). 
types of infringements on freedom of expression. ${ }^{80}$ That being said, Canada does apply the Oakes test in a context-specific way, giving a lower amount of protection to commercial speech than to other types of protected expression (e.g., political speech). ${ }^{81}$ As stated by the Canadian Supreme Court in Rocket v. Royal College of Dental Surgeons:

While the Canadian approach does not apply special tests to restrictions on commercial expression, our method of analysis does permit a sensitive, case-oriented approach to the determination of their constitutionality. Placing the conflicting values in their factual and social context when performing the $\mathrm{s}$. 1 analysis permits the courts to have regard to special features of the expression in question .... [N]ot all expression is equally worthy of protection. Nor are all infringements of free expression equally serious. ${ }^{82}$

In Rocket, the Court suggested that because the case involved commercial speech-as opposed to political participation or artistic expression-" "restrictions on expression ... might be easier to justify than other infringements of [Section] 2(b)." ${ }^{83}$ But at the same time, the Court also recognized that the commercial speech at issue, which was advertising by dentists, also had value to consumers. ${ }^{84}$ The Court wrote that these two factors must be weighed against one another, and in this case, it held that the restrictions on dental advertising were overbroad and must be invalidated. ${ }^{85}$

This analysis demonstrates that the general framework of the Canadian commercial speech analysis is quite similar to that used by U.S. courts. While the Canadian Supreme Court's decisions may be somewhat less protective of commercial speech in comparison to the U.S. Supreme Court, it has shown itself willing to strike down measures that it deems to be unjustified or overbroad infringements on the right to freedom of commercial expression. ${ }^{86}$

\section{B. TOBACCO ADVERTISING}

In the 1995 case RJR-MacDonald, Inc. v. Canada, the Supreme Court of Canada applied its commercial speech jurisprudence to tobacco advertising for the first time. ${ }^{87}$ The law at issue, the Tobacco Products Control Act, included a broad ban on tobacco advertising and promotion (with some exceptions), and it required tobacco packaging to include health warnings. ${ }^{88}$

While all Justices agreed that tobacco advertising fell within the purview of Section 2(b), the Court split five-to-four on whether the regulations survived the Central Hudson-like review under Section $1 .^{89}$ In a decision similar in many respects

${ }^{80} I d$. at 46 (stating that the Canadian Supreme Court "took as a matter of faith that the Charter was not confined to the protection of political expression" and applied Oakes to all forms of expression).

${ }^{81}$ See Rocket v. Royal Coll. of Dental Surgeons of Ont., [1990] 2 S.C.R. 232, 246-47 (Can.).

${ }^{82} \mathrm{Id}$.

${ }^{83} \mathrm{Id}$. at 247.

${ }^{84} \mathrm{Id}$.

${ }^{85}$ See id. at 251.

${ }^{86}$ See Gower, supra note 77, at 56 (writing that the Canadian Supreme Court "is cognizant of the importance of commercial expression to consumers' economic decision-making and does its part to protect commercial expression on the basis of its role in a free marketplace").

${ }^{87}$ RJR-MacDonald Inc. v. Canada (Att'y Gen.), [1995] 3 S.C.R. 199 (Can.).

${ }^{88}$ See id. at 200.

${ }^{89}$ See id. at 204. 
to Lorillard (which postdated it), the Court held that the ban on advertising was rationally connected to the government's interest in reducing tobacco use (parallel to the Prong 3 analysis under Central Hudson). ${ }^{90}$ However, the Court then concluded that the advertising ban was overbroad (similar to the Prong 4 analysis that doomed the restriction in Lorillard). ${ }^{91}$ As in Lorillard, the Court focused on the interest of consumers in obtaining information relevant to their decisions, writing that "the advertising ban deprives those who lawfully choose to smoke of information relating to price, quality, and even health risks associated with different brands." 92 The court also invalidated the requirement for health warnings on cigarette packages, because the government had not shown that it would have been less effective to require warnings that were attributed to the government. ${ }^{93}$

Rather than abandon its efforts to restrict tobacco advertising, the government responded by adopting new tobacco control measures intended to address the Court's concerns. The Tobacco Act of 1997 maintained the broad prohibition on tobacco advertising but created a new exception for "information advertising or brand preference advertising," so long as such advertising was primarily directed towards adults. "94 "Information advertising" was defined to mean advertising about a product's availability and/or price, while "brand-preference advertising" was defined as advertising about a product's brand characteristics. ${ }^{95}$ The law explicitly prohibited "lifestyle advertising," defined as "advertising that associates a product with . . . a way of life such as one that includes glamour, recreation, excitement, vitality risk or daring." ${ }^{, 96}$ In short, tobacco companies could advertise only the "cold, hard, facts" about their products - and only to adult consumers. ${ }^{97}$ Additionally, tobacco companies were barred from advertising in any way that was "false, misleading or deceptive or ... likely to create an erroneous impression about the characteristics, health effects or health hazards of the tobacco product or its emissions." 98 Separately, the Parliament also reissued the regulations governing health warnings on tobacco packaging, increasing the size of the warnings from thirty-three percent to fifty percent of the package space, and clearly attributing the warnings to Health Canada (Canada's Ministry of Health)..$^{99}$

The tobacco companies challenged the revised laws as violating their rights to freedom of expression. In Canada v. JTI-MacDonald Corp. (2007), the Canadian Supreme Court upheld all of the challenged provisions in a unanimous decision. ${ }^{100}$ As in RJR-MacDonald, the Court agreed that tobacco advertising fell within Section 2(b) of the Charter. ${ }^{101}$ The analysis focused almost entirely on whether the

${ }^{90}$ See id. at 206.

${ }^{91}$ See id. at 207.

${ }^{92} I d$. at 347 (emphasis added).

${ }^{93}$ See id. at 349 .

${ }^{94}$ Tobacco Act, S.C. 1997 , c. $13, \S 22(2)$. Such advertising was permitted only if directly mailed to adults, in publications with eighty-five percentor more adult readership, or in places youth were not permitted to go. See WORLD HEALTH ORG., CANADA'S FIRST (TWO-YEAR) IMPLEMENTATION REPORT: ANNEX 1: MISCELLANEOUS 42 (2007) (Can.), available at http://www.who.int/fctc/reporting/Canada annex_miscellaneous.pdf.

${ }^{95}$ See Tobacco Act $\S 22(4)$.

${ }^{96} \mathrm{Id}$.

${ }^{97}$ See id. $\S 22$.

${ }^{98}$ See id. $\$ 20$.

${ }^{99}$ Canada (Att'y Gen.) v. JTI-MacDonald Corp., [2007] 2 S.C.R. 610, para. 7 (Can.).

${ }^{100}$ Id. at para. 141.

${ }^{101}$ See id. at para. 72 . 
challenged provisions were saved by the operation of Section 1. The Court applied the Oakes test as follows:

- Substantial Governmental Concern: The Court quickly determined that the interest at stake--"protecting the health of Canadians and responding to a national health problem"-was one of fundamental importance. $^{102}$

- Rational Connection: The Court noted the incredible amount of new evidence that had emerged between 1995 and 2007 confirming the addictiveness of tobacco, demonstrating the harm caused by smoking, and linking tobacco advertisements to initiation and increased use. ${ }^{103} \mathrm{It}$ also recognized-as U.S. courts often fail to do ${ }^{104}$ - that the "factual context of a long history of misleading and deceptive advertising by the tobacco industry" suggests a strong need to closely constrain the industry's actions. $^{105}$

- Minimal Impairment: As usual, this was the main point of contention. ${ }^{106}$ This section of the analysis was the point at which the differences between the law challenged in RJR-MacDonald and the revised version of the Tobacco Act were crucial. The Court wrote that the law protected the ability of tobacco companies to communicate information to current smokers, while prohibiting "lifestyle advertising" that "invariably seeks to increase overall tobacco consumption, not just to inform existing smokers." 107 This addressed Parliament's legitimate interest in reducing tobacco use while still protecting the right of consumers to obtain relevant information.

- Proportionality Between Effects and Objective: This is the balancing part of the Oakes test that has no direct corollary in the Central Hudson test. In this case, this additional section of the test was central to the analysis because it provided the Court with the opportunity to underscore the importance of the specific context. It wrote that the harms addressed by the legislation were real and pressing ("nothing less than a matter of life or death for millions of people"), ${ }^{108}$ whereas "[w]hen commercial expression is used, as alleged here, for the purposes of inducing people to engage in harmful and addictive behaviour, its value becomes tenuous." ${ }^{, 109}$ In other words, not all commercial speech is created equal. When commercial speech is used in a way that directly threatens the health of a large segment of the population, the Parliament may act with a freer hand. ${ }^{110}$

With regard to the larger warning labels, the Court conducted a separate Oakes test analysis. It found both a sufficiently important governmental concern and a "mass of evidence" supporting the rational connection between the means used and

${ }^{102}$ Id. at para. 38.

${ }^{103}$ See id. at paras. 9-10.

${ }^{104}$ In Lorillard, for example, neither the majority opinion nor the dissent included any reference to the industry's history of misconduct. See Lorillard Tobacco Co. v. Reilly, 533 U.S. 525 (2001).

${ }_{105}$ JTI-MacDonald Corp., 2 S.C.R. at para. 61.

${ }^{106}$ See id. at para. 100.

${ }^{107} \mathrm{Id}$. at para. 102.

${ }^{108} \mathrm{Id}$. at para. 68.

${ }^{109} \mathrm{Id}$. at para. 47.

${ }^{110} \mathrm{Id}$. 
the government's objectives. ${ }^{111}$ Notably, it used the tobacco industry's objection to the larger warnings as evidence of the warnings' likely effectiveness. ${ }^{112}$ Turning to the issue of "minimal impairment," the Court simply stated, "[T]he evidence established that bigger warnings may have a greater effect. Parliament is not required to implement less effective alternatives." "113 Finally, the Court looked to the experience of other countries for additional support, citing both the World Health Organization's Framework Convention on Tobacco Control (FCTC) ${ }^{114}$ and the fact that other countries including "Austria, Belgium, Switzerland, Finland, Singapore, and Brazil" required warnings that cover at least fifty percent of the package. ${ }^{115}$ (After the JTI-MacDonald decision, Parliament passed a new law increasing the size of the required warning labels to seventy-five percent of the package surface. ${ }^{116}$ This new requirement is currently being challenged in court. ${ }^{117}$ )

Thus, in its two cases on tobacco advertising, the Canadian Supreme Court has shown that it will defer broadly, but not blindly, to the Parliament. Although it is hesitant to second-guess Parliament's policy judgments, it is also unwilling to accept blanket prohibitions on commercial speech, even in the context of tobacco. It is wary of restrictions on "information advertising," but is more willing to accept restrictions on "lifestyle advertising" that do not communicate any substance of value. ${ }^{118}$

\section{A COMPARATIVE DISCUSSION: THE BALANCE BETWEEN COMMERCIAL SPEECH AND PUBLIC HEALTH}

As the preceding conversation demonstrates, the First Amendment-and the U.S. commercial speech doctrine, more specifically-is not unique. Other countries, including our neighbor to the north, provide constitutional protection for commercial speech and must consider how to balance the interest in free expression against other key societal interests. ${ }^{119}$ In Canada, the Oakes test used is quite similar, at least in its language and structure, to the Central Hudson test. Both tests require an examination of the government interest involved, the extent to which the proposed restriction promotes the government's interest, and whether the government's approach is appropriately tailored to the problem at hand. ${ }^{120}$

The case of tobacco marketing, where the commercial speech at issue promotes the sale of a deadly product, provides a window through which to view how different legal systems balance the competing interests involved. Even though the text of the Oakes test closely mirrors the Central Hudson test, U.S. and Canadian courts apply the two tests differently. One way to look at these differing results is to point to the

${ }^{111}$ Id. at para. 135.

112 Id. at para. 136.

113 Id. at para. 137.

${ }^{114}$ Canada and most other nations in the world are parties to the FCTC, but the United States is not. Parties to the WHO Framework Convention on Tobacco Control, WHO FRAMEWORK CONVENTION ON TOBACCO CONTROL, http://www.who.int/fctc/signatories_parties/en/index.html (last updated Dec. 7, 2012). The FCTC states that parties should adopt warning labels that cover at least fifty percent of product packaging. WORLD HEALTH ORG., WHO FRAMEWORK CONVENTION ON TOBACCO CONTROL 10 (2005).

${ }^{115}$ Canada (Att'y Gen.) v. JTI-MacDonald Corp., [2007] 2 S.C.R. 610, para. 138 (Can.).

${ }^{116}$ See Sarah Schmidt, Government Asks Court to Toss out Challenge over Cigarette Pack Warnings, OTTAWA CITIZEN, Nov. 21, 2012, http:/www.ottawacitizen.com/health/ story.html?id=7586355

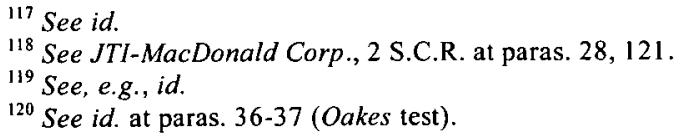


differences in history, culture, and legal practices between the two countries. Another more realist view is to point to differences in the political backgrounds and affiliations of the justices. But looking through a comparative lens is insightful on another level-it helps to unpack some of the values and interests that underlie First Amendment doctrine, or perhaps that have gone missing from more recent developments in U.S. commercial speech doctrine. Examining U.S. commercial speech doctrine in light of the Canadian Supreme Court's tobacco-related decisions suggests several ways in which the U.S. Supreme Court's approach could be reconsidered or reconceptualized.

The comparison is illustrative starting from the origins of commercial speech doctrine in both countries. Both legal systems originally focused on the need to protect and promote the autonomy of consumers. The opinions in Virginia Pharmacy and Ford v. Quebec each emphasized that the primary interest in need of protection was that of the consumer/listener, not the speaker. ${ }^{121}$ If the focus is kept on the consumer, it follows that speech that does not serve the interest in consumer autonomy may be more easily limited. ${ }^{122}$ A company's desire to promote its product in a particular way, for example, is not as highly protected as the consumer's interest in getting truthful information about a given product. As Justice La Forest wrote in RJR-MacDonald, "when the form of expression placed in jeopardy falls farther from the 'centre core of the spirit' [of promoting consumer autonomy and selfdevelopment], this Court has ruled restrictions on such expression less difficult to justify." 123 The main underlying value, then, of the commercial speech doctrine was protecting the consumer from government restrictions.

It is unclear from the U.S. Supreme Court cases whether protecting the consumer meant (1) protecting consumers' autonomy to make their own decisions, or (2) protecting consumers more generally, including protecting consumers' other interests (including their interest in health). In Virginia Pharmacy, these two interests went together. The information at issue (prescription drug prices) was needed to empower informed decision-making, but it was also urgently needed on a much more practical level by consumers who were ill and in need of relief. ${ }^{124}$ The Supreme Court emphasized the importance of both of these interests in Virginia Pharmacy, ${ }^{125}$ but in later cases the focus shifted almost entirely to protecting consumer autonomy (and protecting consumers from governmental

${ }^{121}$ See id. at para. 34 ("When the Charter was adopted, the question arose of whether the free expression guarantee extended to commercial expression by corporations. This Court ruled that it did . ... The Court premised this conclusion on an examination of the values protected by the free expression guarantee: individual self-fulfilment, truth seeking and democratic participation . . . . It noted that commercial speech may be useful in giving consumers information about products and providing a basis for consumer purchasing decisions ....").

${ }_{122}$ When the focus is kept on the interest in promoting consumer autonomy, it also follows that commercial speech targeting children may be more easily restricted than commercial speech directed towards adults. This is the approach that Canada's Supreme Court has taken. See, e.g., id. at para. 94 (noting that "the vulnerability of the young may justify measures that privilege them over adults in matters of free expression"); Irwin Toy, Ltd. v. Quebec (Att'y Gen.), [1989] 1 S.C.R. 927 (Can.) (upholding Quebec's restrictions on marketing directed at children under the age of thirteen).

${ }^{123}$ RJR-MacDonald Inc. v. Canada (Att'y Gen.), [1995] 3 S.C.R. 199, 281 (Can.) (La Forest, J., dissenting).

${ }^{124}$ Va. State Bd. of Pharmacy v. Va. Citizens Consumer Council, 425 U.S. 748, 763-64 (1976) ("When drug prices vary as strikingly as they do, information as to who is charging what becomes more than a convenience. It could mean the alleviation of physical pain or the enjoyment of basic necessities.").

${ }^{125} \mathrm{Id}$. at 763-65. 
"paternalism"126). In the Canadian cases by contrast, the Canadian Supreme Court has remained interested in protecting both interests. ${ }^{127}$ It is concerned about protecting consumer autonomy, but equally concerned about protecting consumers from harm. ${ }^{128}$

This dual concern is demonstrated by the Canadian Supreme Court's decisions in the two tobacco-related cases. First, in RJR-MacDonald, it invalidated the total ban on tobacco advertising because it extended to "advertising which arguably produces benefits to the consumer while having little or no conceivable impact on consumption." 129 The court hypothesized that a complete ban on advertising could apply even to "purely informational advertising" that allowed consumers to "compare brand content with an aim to reducing the risk to their health." ${ }^{130}$ Such information could help inform consumer decision-making and improve health, and thus restricting such advertising was inconsistent with the purposes of the commercial speech doctrine. ${ }^{131}$ Although the Court was willing to approve broad restrictions on tobacco advertising, it was not willing to permit advertising restrictions so broad that they might restrict advertisements that were informative and helpful to consumers.

This formed the basis of the distinction between "informational" and "lifestyle" advertising that the Canadian Supreme Court further developed in JTIMacDonald. ${ }^{132}$ In this later case, the Court recognized that not all advertising communicates information. ${ }^{133} \mathrm{~A}$ key advertising tactic, pioneered in part by tobacco companies but employed by a variety of industries, is to create positive associations with a product without communicating any information. ${ }^{134}$ In the case of cigarettes, such "lifestyle" promotions attract youth to tobacco smoking without providing any useful information to current smokers. ${ }^{135}$ Accordingly, the Court upheld a broad ban on "lifestyle" advertising, while protecting the ability of tobacco companies to communicate "information advertising." 136 By allowing the dissemination of the "cold, hard facts" about tobacco products while prohibiting advertising intended to increase consumption, the Court balanced the potentially competing values underlying the commercial speech doctrine. It permitted consumers to obtain all potentially relevant information, while also protecting the public from harm by restricting non-informational advertising that could increase tobacco use. A key factor in its decision was its recognition of the unique dangers of tobacco. ${ }^{137}$ Because

${ }^{126}$ See, e.g., 44 Liquormart v. Rhode Island, 517 U.S. 484, 503 (1996) (writing that restrictions on truthful commercial speech "usually rest solely on the offensive assumption that the public will respond 'irrationally' to the truth" (quoting Linmark Assocs. v. Willingboro, 431 U.S. 85, 97 (1977))).

${ }^{127}$ See, e.g., RJR-MacDonald Inc., 3 S.C.R. at 343.

${ }^{128}$ See id.

${ }^{129} \mathrm{Id}$.

${ }^{130} \mathrm{Id}$.

131 See id.

${ }^{132}$ Canada (Att'y Gen.) v. JTI-MacDonald Corp., [2007] 2 S.C.R. 610, paras. 96-1 16 (Can.).

${ }^{133}$ Id. at para. 102.

${ }^{134}$ Jon D. Hanson \& Douglas A. Kysar, Taking Behavioralism Seriously: Some Evidence of Market Manipulation, 112 HARV. L. REV. 1420, 1445 (1999).

${ }^{135}$ Indeed, the tobacco industry was largely built on a foundation of this type of image-only advertising: "Cleverly targeted ad campaigns, such as the now-famous Marlboro Man, succeeded in creating demand for Marlboros and other cigarettes by conveying to smokers a sense of independence, autonomy, and sexuality. Not surprisingly, consumers soon associated cigarettes with desirable, abstract traits of the sort that they almost certainly would not have perceived absent effective advertising." See id at 1471 (detailing the tobacco industry's history of misleading advertisements).

${ }^{136}$ JTI-MacDonald Corp., 2 S.C.R. at paras. 96-116.

${ }^{137}$ See id. at para. 9. 
the government's interest was so weighty ("nothing less than a matter of life or death for millions of people"), ${ }^{138}$ the Court granted Parliament more leeway to develop an appropriate response.

How have the U.S. courts furthered these values underlying the commercial speech doctrine? How have they sought to balance consumer autonomy with other consumer interests? As mentioned above, the commercial speech doctrine in the United States started out by emphasizing the interests of consumers. Since that time, however, the focus of the courts has gradually shifted from the consumer to the speaker. The Lorillard decision was a somewhat intermediary step, as the Court emphasized the need to ensure both "the speaker's ability to propose a commercial transaction" as well as the "adult listener's opportunity to obtain information." "139 In the years since, the focus has continued to shift towards the commercial speakers. For example, both the trial court and the appellate court that reviewed the FDA's proposed cigarette warning labels quickly dismissed the public's interest in obtaining the information presented by the labels. ${ }^{140}$ The courts focused instead on the tobacco companies' right to avoid disseminating a message to which they objected. ${ }^{141}$

Very few U.S. cases (and policymakers) have explored the possibility that measures allowing consumers of harmful products to receive only the "cold, hard facts" may be more likely to survive scrutiny than blanket advertising restrictions. One notable exception is a 2009 Fourth Circuit decision (WV Association of Club Owners and Fraternal Services v. Musgrave) upholding West Virginia's strict limits on advertising for video lottery machines. ${ }^{142}$ The Court's conclusion that the law survived the fourth prong of Central Hudson was based in part on the ability of retailers to display a uniform sign stating "West Virginia Lottery Products available here." 143 The Fourth Circuit wrote that allowing only this type of informational advertising "achieves the state's goal of balance: it informs consumers that lottery products are available, but it does not prey on vulnerable populations." 144 Although it is an outlier, the Musgrave decision suggests how U.S. courts could give more consideration to the informational value of speech being restricted. This might lead to more flexibility in cases that involve "pure" marketing devoid of informational content.

With respect to consumer interests such as health, U.S. courts have failed to clarify how the non-informational interests of consumers might be factored into the Central Hudson balancing test. It is no longer clear in U.S. case law whether cases involving cigarettes (which are inherently deadly) should be treated differently from products involving pharmaceuticals (which are potentially life-saving). Some U.S. courts have gone so far as to suggest that protecting consumers from the harms of

${ }^{138}$ See id. at para. 68.

${ }^{139}$ Lorillard v. Reilly, 533 U.S. 525, 529 (2001) (emphasis added).

${ }^{140}$ To the extent Judge Leon discussed this issue, he asserted that warnings were "crafted to evoke a strong emotional response" and not to inform consumers. See R.J. Reynolds Tobacco Co. v. FDA, 845 F. Supp. 2d 266, 272 (D.D.C. 2012).

${ }^{141}$ See R.J. Reynolds Tobacco Co. v. FDA, 696 F.3d 1205, 1222 (D.C. Cir. 2012) (concluding by quoting Sorrell's admonition that because the government "finds expression too persuasive does not permit it to quiet the speech or to burden its messengers" (quoting Sorrell v. IMS Health Inc., $131 \mathrm{~S}$. Ct. 2653, $2670(2011))$ ).

${ }_{142}$ WV Ass'n of Club Owners \& Fraternal Servs. v. Musgrave, 553 F.3d 292 (4th Cir. 2009).

${ }^{143}$ See id. at 307.

${ }^{144}$ Id. 
tobacco products may not even be a substantial governmental interest for purposes of First Amendment analysis. ${ }^{145}$

Why is it that the commercial speech doctrine in the United States has strayed so far from its consumer protection origins? As Tamara Piety recently wrote, the commercial speech doctrine, "which was justified on the basis of protection for consumers," has gradually transformed into a doctrine that "protect[s] speakers" interests, even where such speech [is] at the consumers' expense." ${ }^{146}$ One possible explanation, which Piety suggests, is that these developments are in line with the Supreme Court's expanding doctrine of "corporate personhood," as reflected in the Citizens United decision. ${ }^{147}$ The Supreme Court has increasingly made less of a distinction between the First Amendment interests of natural persons and the interests of corporations. ${ }^{148}$

Another reason may be the U.S. courts' concern with government paternalism (a concern that shows up far less in the legal decisions of other countries ${ }^{149}$ ). Courts may be concerned that allowing the government to focus on the consumers' interests may put the government in the position of inappropriately deciding what is "best" for consumers. ${ }^{150}$ This concern seems somewhat beside the point when dealing with a product that incontestably causes illness and premature death. But even if conceding the validity of the concern about paternalism (even in the case of tobacco), it does not explain why U.S. courts do not focus commercial speech protection on informational communication as Canada does.

\section{CONCLUSION}

Using a comparative lens and focusing attention on Canada provides an opportunity to step back and contemplate the direction of recent U.S. commercial speech cases-and to consider the various roads not taken. For instance, what is it about "lifestyle advertising" - devoid of the any information that would be useful to a consumer - that merits the "heightened scrutiny" suggested in Sorrell? In what way does such "lifestyle advertising," particularly for deadly products, serve the interests of consumers? The Canadian experience helps to highlight the distinction between different types of advertising appeals and leads to questions about why such distinctions are absent from U.S. case law.

More broadly, analyzing the experience of Canada brings more attention to the values that underlie-or could underlie-the commercial speech doctrine. In both

${ }^{145}$ R.J. Reynolds Tobacco Co., 696 F.3d at 1219 n.13 ("[W]e are skeptical that the government can assert a substantial interest in discouraging consumers from purchasing a lawful product, even one that has been conclusively linked to adverse health consequences."); see also Nat'l Ass'n of Tobacco Outlets, Inc. v. City of Worcester, 851 F. Supp. 2d 311, 316 (D. Mass. 2012) ("[Plaintiffs] contend that the City has no legitimate interest in prohibiting non-misleading advertising to adults to prevent them from making decisions of which the City disapproves. I agree.").

${ }_{146}$ Tamara R. Piety, "A Necessary Cost of Freedom?" The Incoherence of Sorrell v. IMS, 64 AlA. L. REV. 1, 6 (2012).

${ }^{147}$ See id. at 5 .

${ }^{148}$ On the one hand, Citizens United focused on the political realm-an area in which First Amendment rights are more strictly protected-so the holding may not easily translate over to the commercial realm. See generally Citizens United v. Fed. Election Comm'n, 558 U.S. 310 (2010). On the other hand, if the "corporate personhood" element of Citizens United is emphasized, it is unclear why corporations should be treated less as "persons" in the commercial, as opposed to the political, realm.

${ }^{149}$ SHINER, supra note 56 , at 114.

${ }^{150}$ This concern was also evident in the Virginia Pharmacy decision. Va. State Bd. of Pharmacy v. Va. Citizens Consumer Council, 425 U.S. 748, 770 (1976). 
the United States and Canada, the commercial speech doctrine was created to protect the interests of consumers. In the United States, the courts have never clarified exactly what consumer interests the doctrine is intended to protect, and in recent years the courts have shifted their attention away from consumers altogether. Refocusing on the values underlying the doctrine may help to suggest new ways of reconciling the constitutional protection of free speech with the need to address the death and disease caused by tobacco use. 